\title{
A STUDY ON THE BUTTERFLY FAUNAL DIVERSITY IN VARIOUS FOREST HABITATS IN THE KNUCKLES FOREST RANGE
}

\author{
V A M P K Samarawickrama' and D R N S Rajapaksha² \\ IUCN, Sri Lanka, Horton Place, Colombo \\ 2Post Graduate Institute of Agriculture, \\ University of Peradeniya
}

\begin{abstract}
A butterfly faunal survey was conducted in the Deenston-Nawanagala Nature Trail area on the eastern flank of the Knuckles Forest Range at a 915-1906m of elevation with the objective of studying the butterfly faunal of the area in different habitat types.
\end{abstract}

A field survey was carried out one day per month during August 2002 to August 2003 period. Data collection was done using the 'long-transect method' containing the transect width to the 'visible range' that varied according to the atmospheric conditions.

The following five major habitat types (Listed in the descending order of extent) were identified: Abandoned Tea Lands with Lime Grass, Lowland Semi-evergreen Forest, Sub Montane Forest, Montane Forest and Abandoned Cardamom Areas.

The total number of species recorded was $\mathbf{4 0}$ in seven families

This habitat distribution is as follows: Abandoned Tea Lands with Lime Grass: 27 spp., Lowland Semi-evergreen Forest; 28, Sub Montane Forest; 18, Montane Forest ; 9, Abandoned Cardamom Areas; 13.

Their distribution in the families is; Nymphalidae 12 spp., Papilionidae 8, Pieridac 6, Satyridae 6, Danaidae 5, Lycaenidae 2 and Riodinidae 1. Only the Family Nymphalidae is found in all habitat types.

Three of these species are endemic and altogether five species (Including the three endemics) are nationally threatened.

In the study area the butterfly fauna facing threats due to human and natural causes. Man made fires occur in grasslands where 27 species (54\%) are found. Cardamom cultivation is another factor. Strong winds in some seasons and forest dieback (especially in Nawangala) are natural causes. The need for conserving this butterfly fauna is highlighted in this paper.

Proceedings of the Ninth Annual Forestry and Envinonment Symposium 2003 of the Department of Forestry and Environmental Science, University of Sri Jayewardenepura, Sri Lanka 